\title{
O FAROL, DE ROBERT EGGERS
}

\author{
THE LIGHTHOUSE, BY ROBERT EGGERS
}

O FAROL. Direção (roteiro): Robert Eggers. A24 / RT Features / Regency Enterprises / Parts e Labor. Estados Unidos, Canadá: 2019. América do Norte: A24, 18 out. 2019; Internacional: Focus Features, 2 jan. 2020. 1 DVD. (110 min), p \& b.

\section{Mateus José Lannes Tolentino*}

Podem avisar, pode avisar Invente uma doença Que me deixe em casa pra sonhar (O Rappa, Me deixa)

No final dos anos de 1890 um novo zelador chega a uma remota ilha na Nova Inglaterra para ajudar o faroleiro local e, entre tempestades e goles de querosene, tenta desvendar os mistérios que existem nas histórias de pescador de seu chefe; enquanto o isolamento causa uma escalada da tensão na convivência entre os dois homens, à medida que o tempo passa, lendas locais parecem ganhar vida e aterrorizam o jovem empregado do farol. Não podemos fugir a essa evidência, a confissão se impõe: citemos de imediato que $O$ Farol é um desses filmes que se inscrevem na tradição do cinema autoral e muito pouco ortodoxo que encontramos de tempos em tempos, talvez em cada década. Porque fazer uso do cinema autoral e muito pouco ortodoxo leva à falsa impressão, neste caso, de que ele tem pretensões aparentemente vaidosas e imodestas. Mediante o ato de "causar sensação" no espectador com um espetáculo artificialmente autêntico e criador, $O$ Farol mostra que é fruto de um realizador hábil e talentoso, que lança mão de funções narrativas compreensíveis e pertinentes para explicitar o objetivo ao qual se destina a mensagem de um filme. O som precário e antigo da captação monofônica, a razão comprimida de aspecto, a escala de cinza contrastada, granulada, imersa no escuro, iluminada por fontes de luz restritas remetem ao passado e subtraem o glamour da imagem a fim de, ato contínuo, combinar com a tarefa sem graça que é cuidar daquele farol perdido no meio do nada e isolado de tudo e de todos, enquanto os personagens são obrigados a viver em dependências insalubres e decadentes, apertados, tão desprovidos de privacidade

\footnotetext{
*Graduando em Filosofia pela UFOP. E-mail: mateustolentino@ hotmail.com.br.
} 
que temos o "privilégio" de testemunhá-los em seus momentos mais íntimos, crus e realistas. Em outras palavras: a linguagem visual realça a sensação de aperto, claustrofobia, isolamento e desconforto e, no entanto, a forma da função narrativa e o desejo de evitar espectadores desavisados, que estão de fato à procura de um cinema mais acessível e de um terror por assim dizer mais convencional, levam Robert Eggers a desenvolver uma autoralidade que não se restringe à linguagem visual; antes, a linguagem visual é um reflexo da autoralidade e demais recursos usados para contar a história de $O$ Farol, filme que oferece um mergulho completo no descarrilamento mental visceralmente entranhado em lendas e superstições sobrenaturais que ora motiva ora decorre delas. A metáfora, por mais inesperada que seja, adapta-se estreitamente aos seus pensamentos (a referência a Hypnosis, de Sascha Schneider, é especialmente interessante "pela qualidade alerta e [...] comovente [...] É como se fosse um espírito aparecendo de repente, ou um relâmpago que subitamente iluminasse a noite escura [...] É um momento que mobiliza todo o nosso ser [...]" (BENJAMIN, 1984, p. 185-186)), e em nenhum lugar a essência dessa intuição é proferida de modo mais claro do que em um fragmento de Origem do drama barroco alemão que se refere não à alegoria, círculo temático percorrido ao longo da ordem de exposição do livro, mas à representação dos afetos considerados como fins do espetáculo dramático:

É com efeito característico [...] que a representação dos afetos se torna cada vez mais enfática, ao passo que o delineamento da ação se torna cada vez mais inseguro. $\mathrm{O}$ ritmo da vida afetiva ganha tal velocidade que as ações serenas e as decisões maduras ficam cada vez mais raras. O conflito entre a sensibilidade e a vontade não se limita apenas à manifestação plástica da norma humana [...] mas aparece também em sua manifestação dramática. É o que fica especialmente evidente no caso do tirano. No curso da ação, sua vontade é cada vez mais enfraquecida pela sensibilidade, até que ele mergulha na loucura. (BENJAMIN, 1984, p. 121-122).

Aqui trata-se apenas de substituir o tirano pelo personagem do filme - ou, se preferirem, deixar ficar como está - para se encontrar dito da maneira mais clara como o declínio da sanidade marca a submissão a uma experiência tão enfadonha, aborrecida e ingrata. Numa época em que a automatização ainda não havia sido inventada, só porque calhou de existir uma ilha no meio do mar onde navios podiam bater, eram necessárias pessoas apenas para cuidar de uma luz que evitava que isso acontecesse. E não há mais nada na ilha além do farol, e não há mais nada para fazer além de cuidar do farol e matar o tempo com tarefas triviais. (Em Ouro Preto, domiciliei-me em uma casa cujo agregado era responsável por apagar e acender a luminária do lado de fora todos os dias. Impressionou-me o número de vezes que ele 
realizou essa tarefa, enquanto a noite caía. Era um homem generoso mas sistemático, que se incomodava com as pessoas entrando e saindo das casas, as repúblicas estudantis, um velho no fundo de um quarto. $\mathrm{O}$ espectador de $O$ Farol pode compreender a estranheza que senti.) Bem vistas as coisas, com intenção clara e manifesta $O$ Farol escancara a latrina fétida e emporcalhada da humanidade, tanto a física como a psíquica. Pois além de contar uma trama bem delineada sobre uma tarefa, o filme está interessado em estudar o tipo de sujeito que era atraído para realizar essa tarefa, e o que essa tarefa realizada em condições tão adversas podia ocasionar a ele. Por isso, O Farol é o que podemos chamar de filme de imersão. Depois de um primeiro ato ambientado na lida com os afazeres do farol, o enredo passa a agir de tal modo a aproximar o espectador dos personagens - a essa altura já despojados de todo o glamour que lhes fora inicialmente atribuído pela arte dramática - que vulnerabiliza as figuras que estão sendo retratadas ali, vulnerabilizando o espectador. E se a partir daí o espectador se encontra vulnerável como os personagens, acompanha os personagens naquela rotina de faroleiro, tornase também ele um faroleiro e vivencia aquela experiência de degradação humana junto com os personagens do filme. Apesar de alguns diálogos não parecerem dizer nada, embora nada muito importante pareça estar acontecendo, não obstante a aparência que a trama e os personagens têm de não estarem chegando a lugar nenhum, atribuir sentido a isso dependerá do quanto o espectador consegue de um golpe dois resultados: mergulhar em águas profundas e voltar de lá na posse da pérola, a lágrima da sereia. "Os jesuítas, que conheciam magistralmente o seu público, não devem ter tido audiências compostas exclusivamente de espectadores que soubessem latim. Deviam estar convencidos da velha sentença de que a autoridade de uma afirmação não somente não depende de sua inteligibilidade, como se reforça quando ela é obscura." (BENJAMIN, 1984, p. 229). Se essas águas nem sempre são das mais puras e se muitos detritos nela flutuam, tanto melhor para o realizador, cujos seres poéticos podem assim desenvolver-se mais e engordar com mais facilidade. Porque muito mais do que constatar as coisas que acontecem na história, o importante aqui é saborear a história, que convenhamos não é particularmente apetitosa. Mas por que alguém iria querer isso? Em primeiro lugar: para observar o laboratório dos personagens definhando, o que é legítimo e natural quando se trata do experiente Willem Dafoe; em consequência, não tem forma melhor de elogiá-lo a não ser dizendo que o que vemos aqui é de fato um faroleiro do século XIX chamado Thomas Wake. (Robert Eggers demonstra saber exatamente o que precisa de seu elenco, consegue extrair desde o pequeno expressivo até o exagerado exigente, e faz isso com uma precisão cirúrgica.) Em segundo lugar: trata-se sem sombra de dúvidas de uma experiência ímpar, por meio da qual 
podemos ampliar nossos horizontes e vislumbrar novos panoramas; e como são horizontes e panoramas extremamente desgastantes para serem experimentados na vida real, O Farol nos oferece uma amostra grátis de uma situação degradante na segurança da sala de cinema. É a atitude do homem que se dedica inteiramente a investigar os misteriosos caprichos da sua digestão. E é certo que os movimentos viscerais nesse filme têm mais de gasoso que de sólido. A melancolia e a obstrução intestinal sempre estiveram associadas. Mas, desde que no corpo social os sucos gástricos deixaram de funcionar, um ar sufocante nos persegue; a crise de mercados da mercadoria humana, que conhecemos sob o nome de desemprego, vivida no confinamento de nossas casas, é uma forma de dumping, de colocação dessa mercadoria na praça a preços vis. Assim, o cinema verdadeiramente político se antecipa às coisas, antevendo o isolamento social, como um arauto precursor, em espantosas descrições de um grupo nunca antes mostrado, as condições então inconcebíveis das massas, que só se tornariam públicas em março de 2020, quando a pandemia do novo coronavírus é decretada.

\section{REFERÊNCIA}

BENJAMIN, Walter. Origem do drama barroco alemão. São Paulo: Brasiliense, 1984. 276 p. (Elogio da filosofia). 